\title{
How Children Get to Know and Identify Species
}

\author{
Barbara Jaun-Holderegger ${ }^{1^{*}}(\mathbb{D})$, Hans-Joachim Lehnert ${ }^{2}$, Petra Lindemann-Matthies $^{2}$ \\ ${ }^{1}$ Bern University of Teacher Education, SWITZERLAND \\ ${ }^{2}$ Karlsruhe University of Education, GERMANY
}

Received 26 June 2021 - Accepted 13 August 2021

\begin{abstract}
This study investigated with the help of in-depth interviews and a think-aloud-approach how 10to12-year-old children $(n=46)$ in the Canton of Berne, Switzerland, get to know species, how they identify plants and animals, and for how important they consider species knowledge to be. Own observations and sensual experiences coupled with positive emotions were most prominent when children encountered plants and animals for the first time. Family members helped most in getting to know species, and were more needed in case of plants. When describing plants, children focused less on flower or flower color than on other characteristic traits. In case of animals, special attention was paid on the body, i.e., its size, form and color. Mean knowledge of animals and mean number of traits mentioned per class was positively related. Children considered species knowledge important for utilitarian reasons and because they thought it part of a general education.
\end{abstract}

Keywords: species knowedge; environmental education; primary school; perception of traits

\section{INTRODUCTION}

We only see things in our environment for which we have names. Everything else is as if it is not there [...]. It is true that occasionally, in aesthetic pleasure, one can see a beautiful flower without knowing what kind of plant it is; one is amazed and rejoices in it for a moment; but it slips away again, one cannot hold it in one's memory (Bollnow, 1966, p. 3; translated)

How children get to know species and how they distinguish between different species is not well known. Data from Swiss children are especially lacking. The present research aimed to contribute to this knowledge gap. In 46 in-depth interviews, 10-12-year old children from the canton of Berne, Switzerland, were asked about their experiences, emotions, and persons involved when getting to know local wild plant and animal species. Moreover, in a simulated radio-moderation the children had to describe and identify further species of Switzerland. In addition, children's attitudes towards species knowledge were investigated. The results contribute to a better understanding of species learning from a child's perspective and the importance attached to it.

\section{Nature Experiences, Perception and Recall of Species}

Nature experiences and frequent contact with plants and animals are important for children's health and well-being (Chawla, 2015; Gill, 2014; Louv, 2006). Nature experiences can be of very different kinds, from picking flowers to bird watching, fishing or hiking. They may include aesthetic enjoyments, species observations, utilitarian acts, spiritual encounters or just playful investigations in near-natural places (Bögeholz, 2006: Kellert \& Westervelt, 1983; Kellert, 1993; Louv, 2006) and are usually linked with emotions (Carmi et al., 2015). However, since decades children's daily contact with nature is declining and with it their chance to establish an emotional connection to nature (Louv, 2016; Pyle, 1993; Soga \& Gaston, 2016; Soga et al., 2016). One reason for the decline in nature experiences is fear of the parents. Parents are concerned about traffic danger, injuries or violence and therefore keep children increasingly at home (Bringolf-Isler et al., 2010; Prezza et al., 2005; Tandon et al., 2012). Children also like to stay at home as this allows them to watch television or play

(c) 2022 by the authors; licensee Modestum. This article is an open access article distributed under the terms and conditions of the Creative Commons Attribution License (http://creativecommons.org/licenses/by/4.0/). 


\section{Contribution to the literature}

- Children's knowledge of living beings is more influenced by sensory experiences and families than by school.

- Plant identification keys for laypersons should focus less on flower color and more on other characteristic features such as leaves and stems.

- Children consider species knowledge important, and should thus not be deprived from getting to know organisms at school.

electronic/video games (Charles \& Louv, 2009; Clements, 2004; Mullan, 2019; Rideout et al., 2010). As a consequence, children's initial contact with plants and animals will increasingly be realized through electronic media, books or attended visits to zoos, parks and other locations rather than original hands-on experiences in near-natural places, as studies already exemplify (Campos et al., 2012; Patrick et al., 2013). However, getting served creatures on a tray may not raise children's curiosity to learn more about plants and animals and to explore their specific characteristics, i.e., an essential prerequisite for identifying species and recognizing biodiversity (Eberbach \& Crowley, 2009). Moreover, since decades little time is spent on organismic biology and hands-on investigations of plants and animals at school, which cannot compensate the decline in out-of-school nature experiences (Barker et al., 2002; Leather \& Quicke, 2009; Pyle, 2002).

If nature experiences are made, in particular first encounters with plants and animals, what will influence if and how they are remembered? First of all it depends on the species itself. Plants are often not consciously perceived as individuals or individual species, but rather as a uniform green matter, for reasons that in nonflowering plants or plants with inconspicuous flowers, edge-detection is difficult due to chromatic and spatial homogeneity and the overlap of green leaves (Wandersee \& Schussler, 1999, 2001). Moreover, due to a lack of movement (at least for the human eye) plants do not protrude from a surface, but blend in as a backdrop (Wandersee \& Schussler, 2001). In consequence, plants are perceived more poorly than animals and, as attention tests show, also recalled less frequently (Balas \& Momsen, 2014; Schussler \& Olzak, 2008). Society's lack of attention to plants is also referred to as "plant blindness" (Wandersee \& Schussler, 1999, 2001).

Animals are better recalled than plants, most likely because humans have stored information about their danger or uses (predators or prey) during evolution (Barrett \& Broesch, 2012; New et al., 2007). However, how well animals are perceived strongly depends on how closely related they are to humans. Mammals are more likely to be perceived than other vertebrates, which in turn are more likely to be perceived than invertebrates (Batt, 2009; Bermudez et al., 2017; Huxham et al., 2006; Lindemann-Matthies, 2005; Patrick et al., 2013). Nevertheless, the concept of life is much more strongly associated with humans and animals than with plants, which are also considered less important (Yorek et al., 2009). In contrast to mammals, which are often considered charismatic (Albert et al., 2018), invertebrates are more likely met with disgust, fear, or avoidance (Breuer et al., 2015; Borgi \& Cirulli, 2015; Prokop \& Randler, 2018). However, not all invertebrates are met with disgust or fear. In a recent study from Switzerland, butterflies, for example, were seen as pleasant, confidence-inspiring species (Breuer et al., 2015).

Children's memories of their first encounter with plants and animals might not only depend on the species involved, but also on the attitudes of the people present. Children were found to mirror their family's nature orientation and displayed negative attitudes towards organisms if this was the case for their parents (Soga et al., 2018). However, the role of other people when getting to know species remains poorly understood.

\section{Identification Skills and Association with Species Knowledge}

The ability to recognize characteristic traits of organisms and similarities or differences between them is fundamental for species identification and taxonomic knowledge (Leather \& Quicke, 2009; Tomkins \& Tunnicliffe, 2015). However, few studies so far have investigated how people identify plant and animal species, and even fewer have focused on children (Tunnicliffe \& Reiss, 1999, 2000). In a recent study from Germany, student teachers were asked about their identification strategies (Lindemann-Matthies et al., 2017). In case of plants, student teachers strategies differed according to the place where the species had to be identified. In the classroom, student teachers would identify plants primarily by their flower characteristics, i.e., the primary feature for identifying whole plant families (Eberbach \& Crowley, 2009). In nature, however, they would identify specimens by their leaves, as flowers might not always be present or, as in many tree species, too high-up. For student teachers, the color of a flower hardly played a role. When animals had to be identified, size, shape, and color were the most important determination criteria (Lindemann-Matthies et al., 2017; Palmberg et al., 2015; Tunnicliffe \& Reiss, 1999).

Little is known about whether there is a relationship between the number of traits children can use in 
identifying organisms and their knowledge of species. Previous research has rather focused on associations between species knowledge and children's connection to nature, socio-demographic variables, and degree of education (Hooykaas et al., 2019) or the impact of different educational approaches on the number of animal species identified (Randler, 2008; Randler \& Bogner, 2002). For a sound understanding of biological diversity, however, it is not only important to retain species names, but above all to be able to distinguish between organisms on the basis of a wide range of characteristic traits. It is also important to recognize trait differences within species, as this is the only way to understand selection as a mechanism of evolution (Bermudez \& Lindemann-Matthies, 2020; Galli \& Meinardi, 2015).

\section{Importance of Species Knowledge}

Whether people want to deal at all with species and want to know their names depends on how significant they consider species knowledge to be. There are many reasons why species knowledge is important and should be fostered (Leather \& Quicke, 2009). However, these reasons are normally provided by scientific experts and not by laypersons. From the expert point of view, knowledge of species is everyday knowledge that helps people to classify and understand the world, sensitizes them to their fellow creatures, and enables them to deal with nature in a caring and protective manner (Leather \& Quicke, 2009; Papworth et al., 2009; Slingsby, 2009; Zucchi, 2007). The ability to name an organism gives people the power to place it within its ecological context and in doing so provides further insights (Leather \& Quicke, 2009). Moreover, knowledge of species is indispensable for acquiring the competence to protect biodiversity (Lindemann-Matthies, 2005; Leather \& Quicke, 2009, 2010). However, in recent decades natural history has more and more disappeared from school curricula in European countries (Barker et al., 2002; Leather \& Quicke, 2009). In addition, children have increasingly less contact and experiences with nature, which can lead to a loss of emotional affinity toward nature (Louv, 2006; Soga \& Gaston, 2016). In consequence, children might no longer feel that knowing species and their names is important.

\section{Sources of Species Knowledge}

Although there are many reasons why species knowledge should be fostered, the question arises who provides this knowledge. Here, studies show a rather mixed picture. In two recent studies from Germany, parents and school were named as the most important sources of species knowledge (Lindemann-Matthies et al., 2017; Remmele \& Lindemann-Matthies, 2018), while in studies from Nordic-Baltic countries and the UK, media such as television, books or the Internet were more important than family or school (Palmberg et al.,
2015; Patrick \& Tunnicliffe, 2011; Patrick et al., 2013). However, children at pre-school age were less likely to mention the media than older children (Gatt et al., 2007; Tunnicliffe et al., 2008; Tunnicliffe \& Reiss, 1999, 2000). For older children, parents and own observations in nature seemed to be the most important information sources (Gatt et al., 2007; Tunnicliffe \& Reiss, 1999, 2000). More than three decades ago, nine to twelve-year-old children in Germany also mentioned their grandparents as a source of knowledge (Scherf, 1988). However, it is hardly known who or what helps children to retain the names of plants and animals.

\section{Main Objectives and Research Questions}

The present study wanted to investigate how children get to know species, which characteristic traits they notice and what they basically think about species knowledge. The following questions guided the research:

(Q1) What were children's experiences and emotions during their first encounter with species and which persons were involved?

(Q2) Which characteristic traits do children use to identify plant and animal species, and is the number of traits used related to species knowledge?

(Q3) Do children consider species knowledge important for themselves and for society and, if so, for what reasons?

(Q4) Who or what helps children to retain the names of species?

\section{METHODS}

\section{Overview}

Interviews were conducted with 46 children from twelve classes and nine schools in the Canton of Berne, Switzerland. The schools were located in different municipalities with different population densities. However, only two of the nine schools were located in a rural settlement area. The selection of children was based on the results of a prior species identification test in which all children $(n=241)$ from the respective classes had participated (authors, in prep.). In this test, common wild plant and animal species of Switzerland (69 plants and 67 animals) were presented as photographs and children asked to identify the organisms by their common German names (mean number of species correctly identified: $39.3 \pm 0.80)$. In each class, two children from the 25-percentile (between 21-48 correct identifications) and further two from the 75-percentile (40-74 correct identifications) were preselected for the present interviews. Between two and four children per class finally participated (written consent of their parents). The children (23 girls and 23 boys) were between ten and twelve years old (mean age $=11.3$ years, 
$\mathrm{SD}=0.73$ ). All spoke Swiss German or German at home and in school, and could thus rather fluently express themselves.

Data were collected at school, and children needed between 11 and 33 minutes for an interview (on average 22.9 minutes, $\mathrm{SD}=4.3$ ). The length of an interview was unrelated to children's age, sex or species knowledge (all $p>0.158)$. Special attention was paid to ensure that the children felt comfortable during the interviews. At any time, they could ask questions, and received favourable responses to assumptions and statements. To avoid the impression of a test situation, the interviews were not carried out in the classrooms, but in other locations at school that provided a friendly atmosphere. All children and their parents were informed in advance about the main research objective (children's learning about species) and study method (face-to-face interviews), and anonymity was guaranteed to the participants.

\section{The Interviews}

Semi-standardized interviews with stimulus material in form of pictures, preparations and potted plants were used. The interviews consisted of four parts that differed in content and methodology.

Part 1 (research question 1): The first part of the interview investigated children's personal experiences when getting to know organisms. One after the other, pictures or living specimens of two plant and two animal species were presented (list of species in Appendix 1). The children were asked to name the species and to explain how they had gotten to know them. In doing so they were asked to describe the persons involved, the places and occasions, and whether they remembered the first contact as a positive or negative experience. Children could freely talk about their experiences in a relaxed atmosphere and were only interrupted for a better understanding.

To begin with, all children were shown a stinging nettle (Urtica dioica) and a wood ant (Formica sp.). In the previous survey on species knowledge, the stinging nettle was identified at the species level by $72 \%$ of the children and the wood ant as an ant by $96 \%$. It was therefore assumed that the children could report on experiences with these two organisms. It was also assumed that both organisms might have caused negative reactions at a first encounter, which are remembered (as in Scherf, 1988). The stinging nettle was presented as a picture and the wood ant as a live catch in a plastic container. In order to increase the probability that the children could also report an experience with the other two organisms presented, they were selected among those species that a child had correctly named in the written survey. If this was not possible because the child did not know enough species by name, a plant or an animal were selected that most of the other children had correctly identified. This increased the probability that, even without knowing the name, an experience could be reported.

Part 2 (research question 2): The second part of the interview investigated how children describe the outer appearance of organisms. Here, an applied form of a think-aloud survey was used. Children were shown, one after the other, two plants and two animals they had to portray. They were informed in advance that they were now radio presenters and would have to describe the respective organisms aloud to their listeners. In doing so, they were to name all the characteristics that could be important for the identification of the species. If possible, the name of the respective organism should be mentioned at the end. A table microphone helped children to immerse in their role.

The four organisms were wild strawberry (Fragaria vesca), herb-Robert (Geranium robertianum), common pipistrelle (Pipistrellus pipistrellus), and leather beetle (Carabus coriaceus) (see Appendix 2). The two plants were presented in flowerpots and had both flowers and fruits. The bat was presented as a picture and the beetle as a needled specimen. The selection of species was based on the results of the preceding survey. Two species were selected that had been familiar and further two unfamiliar to the children. F. vesca had been correctly identified as a strawberry by $84 \%$ and $P$. pipistrellus as a bat by $99 \%$ of the children. G. robertianum, in contrast, had been identified as a cranesbill by only one child, and C. coriaceus had been totally unknown. To get children going, the familiar plant or animal species was always shown first and then followed by the unfamiliar plant or animal.

Part 3 (research question 3): In the third part of the interview the children were asked whether they thought it important to know the names of plants and animals. They were asked to explain the relevance (or irrelevance) of species knowledge first for themselves and then for society.

Part 4 (research question 4): In the fourth part of the interview, the children were asked who or what helps them most to learn about species and their names.

\section{Pilot Test and Data Analysis}

The interviews were pilot tested with three children who did not take part in the final interviews. Piloting led to a more precise formulation of the interview questions and the use of a table microphone in the second part of the interview.

All interviews were conducted by the first author. The interviews were videographed using a Sony Handycam HDR-SR12 with a tripod and, in addition, audio-recorded using an Olympus LS-5. This was helpful as in some cases children's statements could be heard better. The videography was transcribed with the program F4. Data were categorized with MaxQDA version 12 . The code plan was continuously revised and 
expanded during the coding process. Two colleagues not involved in the present research checked the coding, resulting in an intercoder relationship of $84 \%$.

The radio moderations of the children were adjusted for empty words, double statements and statements leading away from the task. Subsequently, the number of words was counted for each description of a species. This was done to roughly grasp how detailed a description was, and also to investigate whether plants were described in more detail than animals or vice-versa. In case of the familiar strawberry (Fragaria vesca), 31 of the 46 children mentioned aspects that went beyond the actual task. Typical outtakes were: "In summer they have delicious fruits, but you have to eat them quickly, because otherwise the snails get them." "There are many kinds of ice cream made from strawberries." Even more children (39) mentioned aspects leading away from the task when talking about the common pipistrelle (Pipistrellus pipistrellus). Typical examples were: "Depending on the species it has bigger or smaller ears. The animal has been changed a bit in movies, but the animal itself was not in the movie. It eats insects. During the day it sleeps and hangs upside down on a tree." "The bat hears very well and emits signals at night to notice insects. Some even suck blood." In case of the two unfamiliar species, i.e., herb-Robert (Geranium robertianum) and leather beetle (Carabus coriaceus), outtakes were much less necessary. Only four children added, when describing G. robertianum, that the plant grows in forests or at the edge of forests, and six children felt that $C$. coriaceus eats plants and smaller animals, and that it lives mostly in the forest.

Linear mixed models (type III SS) with class as a random factor were used to test whether the number of traits (plant and animal features mentioned) was related to children's taxonomic knowledge, age and sex. Additionally, data were aggregated at the level of the class and linear regression analyses used to test whether the mean number of plant or animal traits mentioned was related to the mean knowledge of plants or animals. All analyses were carried out with SPSS version 24 .

\section{RESULTS}

\section{First Encounters with Plants and Animals (Research Question 1)}

Almost all children could clearly remember their first encounter with stinging nettles (Urtica dioica) as for most of them it was a rather unpleasant sensual experience. Some children, however, had learned to make tea or soup from nettles which they found interesting (Table 1). About $44 \%$ of the children reported negative feelings when thinking of nettles ("the plant stings"), and only $9 \%$ positive ones ("surprisingly good taste"). 39\% had mixed feelings and the others could not decide. About $39 \%$ of the children could not remember who had told

Table 1. How children $(\mathrm{n}=46)$ got to know stinging nettles (Urtica dioica), other plant species, wood ants (Formica sp.), and other animal species. Responses to the open questions were sorted into broad categories

\begin{tabular}{|c|c|c|}
\hline & $\begin{array}{l}\text { Modality (number of } \\
\text { responses) }\end{array}$ & Illustrative examples (gender, age, feelings) \\
\hline $\begin{array}{l}\text { Stinging } \\
\text { nettle }\end{array}$ & Sensual experiences (35) & $\begin{array}{l}\text { When I was little, I fell on one and it hurt me a lot. Then my mother said it was a nettle. } \\
\text { And I know that now. I have negative feelings when I see a nettle. I say, oh, watch out. } \\
\text { (girl, 11, negative) } \\
\text { We have a meadow. When I was little, I used to go there with my friend. We pushed the } \\
\text { grass down and made sort of a house. Then something burned me and I went home to ask } \\
\text { my mom what it could be. Nettles burn, but they can also cure as tea. (boy, 10, mixed) }\end{array}$ \\
\hline & $\begin{array}{l}\text { Learning situation: } \\
\text { species shown and } \\
\text { explained (4) }\end{array}$ & $\begin{array}{l}\text { When I was little my father told me not to touch them because they sting. I touched them } \\
\text { anyway to see if what he said was true, and then it hurt. Then I knew what nettles are. } \\
\text { They are unpleasant. (boy, 11, negative) }\end{array}$ \\
\hline & $\begin{array}{l}\text { Food preparation and } \\
\text { consumption ( } 2)\end{array}$ & $\begin{array}{l}\text { My mother collects herbs and once we prepared a dish with young nettle leaves. It was } \\
\text { delicious. I dislike the burning, but now I can say that I had eaten them - and that was a } \\
\text { good experience. (girl, 10, mixed) }\end{array}$ \\
\hline
\end{tabular}

Individual Learning situation: plant species shown and species explained (19)

Own observations (11)

Food preparation and consumption (9) Cannot remember (8)
My mother showed me the beech tree on a hike and then she kept giving me nuts. That is how I got to know it. They are great trees, not only because they become very big and beautiful. They give food for squirrels and other forest animals and are super to climb. (boy, 11, positive)

In school we talked about meadows and I got to know red clover. It is a beautiful plant. (boy, 10, positive)

We have ivy at home. As with most things, once you have observed it and it has been explained to you [mother], it is stored. I have never experienced anything bad with ivy. It is poisonous when you eat it. (girl, 10, positive) When I was little, I saw a tree with a funny bark that I liked. My mother told me the name. The birch is my favorite tree. (girl, 12, positive)

We make syrup from elderberry flowers and sometimes I help. I learned the name from my parents. The flowers and berries taste very nice. (boy, 10, positive) 
Table 1 (continued). How children $(\mathrm{n}=46)$ got to know stinging nettles (Urtica dioica), other plant species, wood ants (Formica sp.), and other animal species. Responses to the open questions were sorted into broad categories

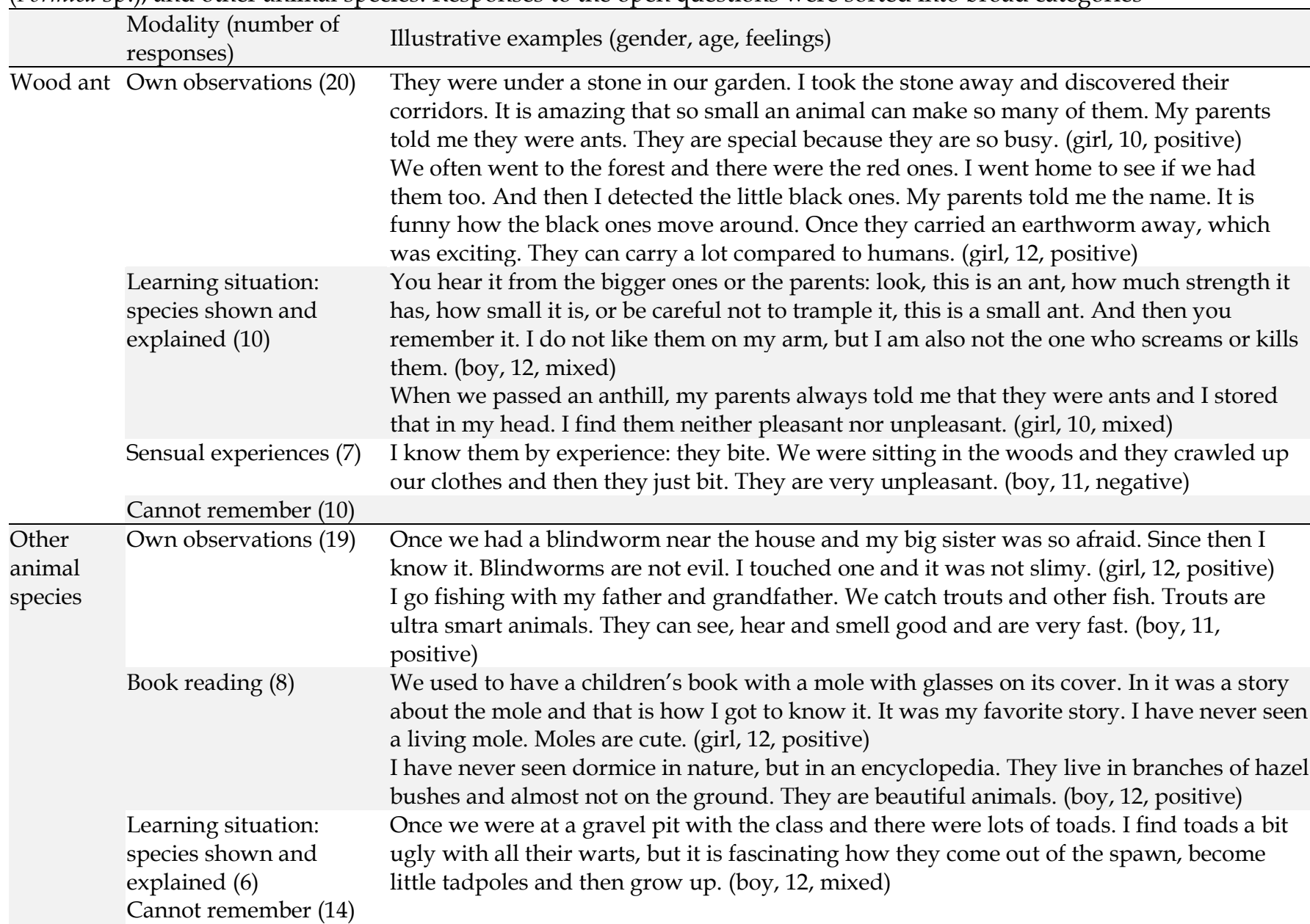

Table 2. Persons involved when children $(\mathrm{n}=46)$ got to know stinging nettles (Urtica dioica), wood ants (Formica sp.), and other plant and animal species. Responses to the open questions were sorted into broad categories. Multiple responses were possible

\begin{tabular}{lccccc}
\hline \multirow{2}{*}{ Persons } & \multicolumn{2}{c}{ Plants (responses) } & & \multicolumn{2}{c}{ Animals (responses) } \\
\cline { 2 - 3 } \cline { 5 - 6 } & Stinging nettle & Other plants & & Wood ant & Other animals \\
\hline Parents & 32 & 6 & 6 & 32 & 12 \\
Grandparents & 6 & 2 & 6 & 3 & 11 \\
Siblings & 0 & 0 & 0 & 4 \\
Teachers & 1 & 12 & 3 & 4 \\
Other persons & 0 & 18 & & 19 & 14 \\
Cannot remember & & & & 3 & 1 \\
\hline
\end{tabular}

them the name of the plant. The others named parents or grandparents, but rarely kindergarten or school as experiences with stinging nettles were made in early years (Table 2, see also Table 1).

Learning situations were frequently mentioned when children remembered their first encounter with the individual plant species presented (see Table 1). As with stinging nettles, family members provided the names (see Table 2). About $65 \%$ of the children associated positive, $2 \%$ negative and $11 \%$ mixed feelings with their plant. The others $(22 \%)$ could not decide.

In contrast to plants, own observations were more prominent than learning situations when children remembered their first encounter with wood ants
(Formica sp.; see Table 1). Again, family members provided the names (see Table 2). About 33\% of the children associated positive, $20 \%$ negative and $41 \%$ mixed feelings with wood ants. The remaining $6 \%$ were unsure.

About $30 \%$ of the children could not remember their first encounter with the individual animal that was shown to them. As with ants, own observations were most prominent (see Table 1). However, in contrast to the other species, books were the second main source of primary knowledge about the individual animal. Species names were, apart from books, provided by family members, but also teachers and other persons such as neighbors (see Table 2). About $48 \%$ of the children associated positive, $22 \%$ negative and $11 \%$ mixed 
Table 3. Features and attributes that children $(\mathrm{n}=46)$ mentioned in their descriptions of wild strawberry $($ Fragaria vesca) and herb-Robert (Geranium robertianum) in a simulated radio moderation. 1st-6th: position in the descriptions; attributes are sorted by frequency

\begin{tabular}{|c|c|c|c|c|c|c|c|}
\hline & \multirow{3}{*}{ Features } & \multicolumn{4}{|c|}{ Proportion of responses (\%) } & \multirow{3}{*}{ Attributes } & \multirow{3}{*}{ Examples } \\
\hline & & \multirow{2}{*}{ Named } & \multicolumn{3}{|c|}{ Position } & & \\
\hline & & & 1st & 2nd & 3rd-6th & & \\
\hline \multirow[t]{7}{*}{$\begin{array}{l}\text { Wild } \\
\text { strawberry }\end{array}$} & Fruit & 97.9 & 43.5 & 10.9 & 43.5 & $\begin{array}{l}\text { color, form, } \\
\text { size, texture }\end{array}$ & $\begin{array}{l}\text { ripe fruits red, unripe ones yellow; oval-round, } \\
\text { quite small; grainy, with hairs }\end{array}$ \\
\hline & Leaf & 89.1 & 28.3 & 39.1 & 21.7 & $\begin{array}{l}\text { form, color, } \\
\text { size, texture }\end{array}$ & $\begin{array}{l}\text { three-lobed, jagged, roundish; green with black } \\
\text { spots; medium-sized; fine, hairy }\end{array}$ \\
\hline & Flower & 76.1 & 8.7 & 23.9 & 43.5 & color, size & white, white petals and yellow stamens; small \\
\hline & Stem & 49.9 & 13.0 & 15.2 & 21.7 & $\begin{array}{l}\text { texture, color, } \\
\text { size, form }\end{array}$ & $\begin{array}{l}\text { with fine thin hair, coarse; green, brownish-red; } \\
\text { long, branched }\end{array}$ \\
\hline & Bud & 8.8 & 0.0 & 0.0 & 8.8 & form, color & like a styrofoam ball; yellow-red \\
\hline & Stolone & 6.5 & 0.0 & 0.0 & 6.5 & & \\
\hline & Appearance & 23.9 & 6.5 & 8.7 & 8.7 & size, form & $10 \mathrm{~cm}$, thin \\
\hline \multirow[t]{5}{*}{$\begin{array}{l}\text { Herb- } \\
\text { Robert }\end{array}$} & Flower & 97.8 & 19.6 & 30.4 & 47.8 & $\begin{array}{l}\text { color, size, } \\
\text { texture }\end{array}$ & $\begin{array}{l}\text { pink-red petals, violet-red; rather small; fine } \\
\text { hairs }\end{array}$ \\
\hline & Leaf & 93.3 & 21.7 & 32.6 & 39.0 & $\begin{array}{l}\text { form, color, } \\
\text { size, texture }\end{array}$ & $\begin{array}{l}\text { carot-like, triangle-like, circular shaped, jagged; } \\
\text { green, at exterior red; small; fine, with hairs }\end{array}$ \\
\hline & Stem & 76.1 & 37.0 & 23.9 & 15.2 & $\begin{array}{l}\text { color, texture, } \\
\text { size }\end{array}$ & $\begin{array}{l}\text { red at bottom and green at top; with hairs; } \\
\text { medium tall, very long }\end{array}$ \\
\hline & Bud & 71.8 & 2.2 & 8.7 & 60.9 & $\begin{array}{l}\text { form, color, } \\
\text { size, texture }\end{array}$ & $\begin{array}{l}\text { bowl-shaped at bottom, pointy at top; purple, } \\
\text { pink with black tip; small; with fine hairs }\end{array}$ \\
\hline & Appearance & 32.5 & 19.6 & 4.3 & 8.6 & size, form & $20-30 \mathrm{~cm}$, tall, longish \\
\hline
\end{tabular}

feelings with their individual animal, and $19 \%$ were undecided.

\section{Traits Used in Species Identifications (Research Question 2)}

The children mentioned four to six different features in their descriptions of the two plant species (Table 3), and eight to nine different ones in their descriptions of the two animal species (Table 4). Moreover, up to four different attributes were used in children's descriptions, depending on the species and body parts. To determine whether there was a relationship between the characterization of plants and that of animals, it was first calculated how many features a child had named for the two plant species (Fragaria vesca and Geranium robertianum) and then for the two animal species (Pipistrellus pipistrellus and Carabus coriaceus). The same procedure was performed for the number of attributes mentioned for the two plant species and for the two animal species. The total number of plant features and the total number of animal features named by a child were positively correlated (Pearson correlation coefficient $r=0.678, p<0.001)$, as was the total number of plant attributes and animal attributes $(\mathrm{r}=0.668, \mathrm{p}<$ 0.001 ). Moreover, the total number of plant features was positively correlated with the total number of plant attributes $(r=0.686, p<0.001)$, as was the total number of animal features and animal attributes $(\mathrm{r}=0.801, \mathrm{p}<$ 0.001).

In case of $F$. vesca, the children most often referred to fruits and leaves (see Table 3 ). The sequence, in which the different features were described, showed some distinct patterns. Ten children started their description with the sequence 'fruit, leaf' and further ten with 'stem,

Table 4. Features and attributes that children $(\mathrm{n}=46)$ mentioned in their descriptions of common pipistrelle (Pipistrellus pipistrellus) and leather beetle (Carabus coriaceus) in a simulated radio moderation. 1st-7th: position in the descriptions; attributes are sorted by frequency

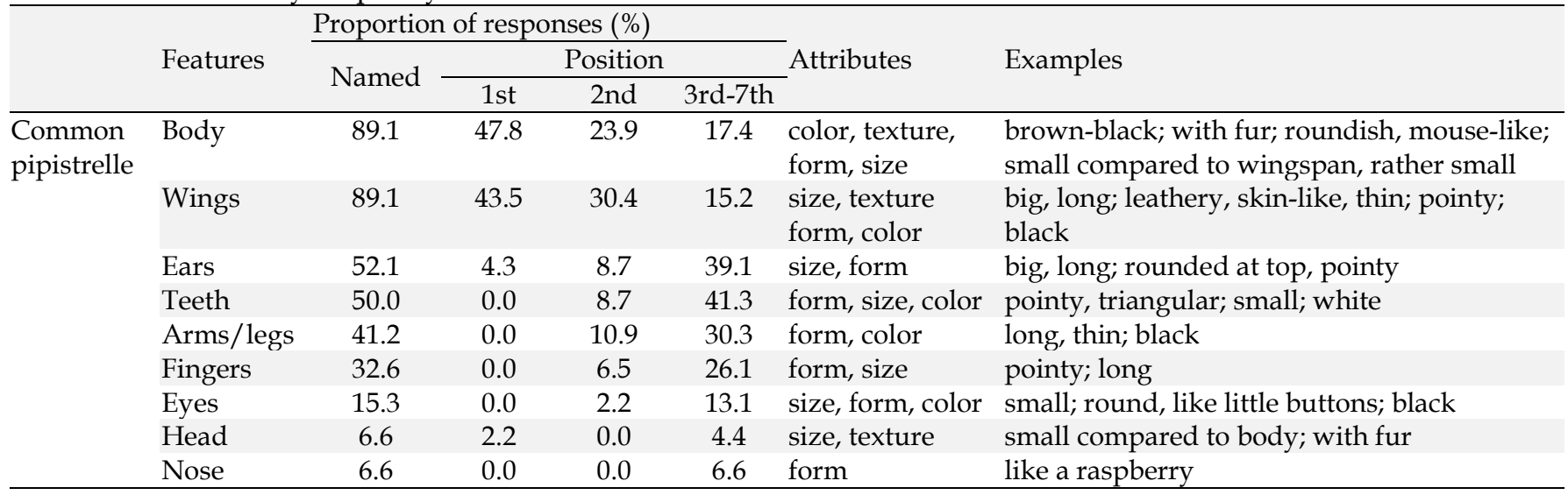


Table 4 (continued). Features and attributes that children $(n=46)$ mentioned in their descriptions of common pipistrelle (Pipistrellus pipistrellus) and leather beetle (Carabus coriaceus) in a simulated radio moderation. 1st-7th: position in the descriptions; attributes are sorted by frequency

\begin{tabular}{|c|c|c|c|c|c|c|c|}
\hline & \multirow{3}{*}{ Features } & \multicolumn{4}{|c|}{ Proportion of responses (\%) } & \multirow{3}{*}{ Attributes } & \multirow{3}{*}{ Examples } \\
\hline & & \multirow{2}{*}{ Named } & \multicolumn{3}{|c|}{ Position } & & \\
\hline & & & 1st & 2nd & 3 rd-7th & & \\
\hline \multirow[t]{7}{*}{$\begin{array}{l}\text { Leather } \\
\text { beetle }\end{array}$} & Legs & 95.5 & 21.7 & 50.0 & 23.8 & form, size & $\begin{array}{l}\text { three at each side, with hooks, little toes, spikes, } \\
\text { claws, tips, segmented; rear ones very long }\end{array}$ \\
\hline & Body & 94.6 & 71.7 & 13.0 & 9.9 & $\begin{array}{l}\text { color, form, } \\
\text { size }\end{array}$ & $\begin{array}{l}\text { black; tripartite, shield-like, wide at bottom, big } \\
\text { abdomen, slit in middle, breastplate small, } \\
\text { quadratic, little dots at abdomen; length of a } \\
\text { thumb, } 2-3 \mathrm{~cm}\end{array}$ \\
\hline & Antennae & 91.3 & 6.5 & 17.4 & 67.4 & $\begin{array}{l}\text { size, form, } \\
\text { color }\end{array}$ & $\begin{array}{l}\text { very long, big; backwards bent, segmented; } \\
\text { black }\end{array}$ \\
\hline & Mandibles & 56.7 & 0.0 & 2.3 & 54.4 & Form & like a small beak, like brackets, feelers, spikes \\
\hline & Wings & 30.4 & 0.0 & 6.5 & 23.9 & texture, form & rough; curved \\
\hline & Eyes & 28.2 & 0.0 & 2.2 & 26.0 & size, form & big, small; round, circles \\
\hline & Head & 23.9 & 0.0 & 8.7 & 25.6 & size, form & longish, small; oval \\
\hline
\end{tabular}

leaf' or 'leaf, stem' (43.4\%). Only four children $(8.7 \%)$ mentioned the flower first. In case of G. robertianum, flowers and leaves were named most frequently, but most children started with the stem or leaf and only then described the flowers. Thirteen children (28.3\%) used the sequence 'stem, leaf' or 'leaf, stem' and eight (17.4\%) 'flower, leaf' or 'leaf, flower'.

$P$. pipistrellus was mainly described by its body, wings and ears (see Table 4). 23 children (50\%) started with the sequence 'body, wings' or 'wings, body', and only two children $(4.3 \%)$ mentioned neither body nor wings in the first or second place. C. coriaceus was mainly described by its legs, body and antennae. 27 children $(58.7 \%)$ started with 'body, leg' or 'leg, body', and further six (13\%) with 'body, antennae'. Typical descriptions of the four species are shown in Table 5.

After children's moderations had been cleared of empty words, double statements, and statements leading away from the actual task, they consisted on average of 152 words (between 42 and 423 words, median $=141$ ). The total number of words a child had used to describe the two plant species was positively

Table 5. Examples for the descriptions of wild strawberry (Fragaria vesca), herb-Robert (Geranium robertianum), common pipistrelle (Pipistrellus pipistrellus), and leather beetle (Carabus coriaceus) during the simulated radio moderation

$\begin{array}{ll}\text { Wild } & \text { We have a plant here with berries as I have just seen. It has leaves, usually three on a stem, which are jagged. The } \\ \text { strawberry } & \text { flowers are white. Both leaves and the plant have hairs. When the strawberries are not yet ripe, they are yellow. }\end{array}$

The buds are small like a styrofoam ball. (boy, 12 years old)

This plant has green leaves. At a stalk are usually three leaves at the end, which are rather roundish and serrated. The flowers are white. There is something like a root. But they are stems that go back into the earth in another place and take root there. And there is a plant there again. The plant has red berries. At the beginning they are quite small. (girl, 10 years old)

In front of me I have a plant with white petals and yellow inner flowers. This plant has red fruits. The leaves of the plant are quite big compared to the fruits. They have prongs at the ends. The stem of the plant does not get too thick and the plant itself is not very big. As you can imagine, the leaves are green, the fruits are $1 \mathrm{~cm}$ in diameter and quite round. The stem usually stays green, and the plant has several stalks with leaves attached. A quarter of the leaves are withered, i.e., yellow to brown, and one fruit is very dark to wine-red. And this plant is, as you can probably imagine, a strawberry. (boy, 11 years old)

Herb- $\quad$ The plant in front of me has a dark red stem and is $20-30 \mathrm{~cm}$ high. The leaves are quite small, turn into many round Robert parts and have a small prong at the end. The flowers are pur-ple or pink and pointed before they bloom. The stem has small hairs that look like tiny spines on a nettle. The dead leaves first turn reddish, then brown and finally they con-tract. This plant also has several stems, but only on one, the main stem, which is the thickest, are flowers. The leaves do not only grow on the stem, there are also additional stems with leaves. (boy, 11 years old) I can see that the leaves are rounded at the exterior and that the stem has hairs. When flowering, the petals are pink and there are buds that are green and also hairy. (boy, 11 years old)

It does not grow straight out of the ground, but a little diagonal and elongated. When the flower is still closed, it is thicker at the bottom and has very fine little hairs that you can hardly see or feel, and then it goes up to a point. The tip is pink and at the top black or simply dark. The plant, including the leaves, has very fine hairs, as does the flower. When the flower is open, it is rather dark yellow in the middle and the leaves are light purple. But it also has structure in it, so from inside to outside, which is almost white. The leaves look almost like a snow star. There are several of them, but they do not stick together and look like not quite half-open circles, cloudy. The leaves are bigger or smaller, depending on their size. Sometimes, when they are dying, they are red. Especially at the bottom, where the plant comes out of the ground, you can see the hairs on the stem very well. (girl, 10 years old) 
Table 5 (continued). Examples for the descriptions of wild strawberry (Fragaria vesca), herb-Robert (Geranium robertianum), common pipistrelle (Pipistrellus pipistrellus), and leather beetle (Carabus coriaceus) during the simulated radio moderation Illustrative examples

Wild We have a plant here with berries as I have just seen. It has leaves, usually three on a stem, which are jagged. The strawberry flowers are white. Both leaves and the plant have hairs. When the strawberries are not yet ripe, they are yellow. The buds are small like a styrofoam ball. (boy, 12 years old)

This plant has green leaves. At a stalk are usually three leaves at the end, which are rather roundish and serrated. The flowers are white. There is something like a root. But they are stems that go back into the earth in another place and take root there. And there is a plant there again. The plant has red berries. At the beginning they are quite small. (girl, 10 years old)

In front of me I have a plant with white petals and yellow inner flowers. This plant has red fruits. The leaves of the plant are quite big compared to the fruits. They have prongs at the ends. The stem of the plant does not get too thick and the plant itself is not very big. As you can imagine, the leaves are green, the fruits are $1 \mathrm{~cm}$ in diameter and quite round. The stem usually stays green, and the plant has several stalks with leaves attached. A quarter of the leaves are withered, i.e., yellow to brown, and one fruit is very dark to wine-red. And this plant is, as you can probably imagine, a strawberry. (boy, 11 years old)

Leather At the back he is about as broad as a thumb. He has three legs on each side, making six in all. In front the animal beetle has antennae and at the mouth also small feelers. The rear legs are almost like those of a frog, so they are spread out and very long. They go beyond the body at the back. The body consists of three parts: a rear part, then, as with us, the shoulder and the head in front. It is black. The size of the animal is about the length of a thumb. (girl, 10 years old)

Now I have an animal before me that is black all over. It has six legs and two antennae and at the mouth it has four smaller antennae. The animal has a very, very large body compared to the other parts, i.e., legs and antennae, and is very thick. Even its small eyes are black. The animal is about $4 \mathrm{~cm}$ long and with its legs stretched out, i.e., stretched out to the side, it is about 3.5-4 cm wide. The animal has no fur, but a kind of carapace. On the body the carapace is a bit rough and on the head it is very fine. The legs have small claws and so compartments so that it can hold on well. (boy, 11 years old)

It is all black and has two antennae on his head. It has six legs. The two in the back are pretty long. On his head it has two pincers and the eyes are two round balls. The back looks like a tank. (boy, 11 years old)

The animal has six legs and is black. It has two antennae to the right and left of the head. It has a carapace-like rear part and three points at the mouth. At the end of the legs it has small hairs. The legs are together at the beginning and then they go apart towards the end. The four front legs are bent forward and the two hind legs more backward. They are longer than the front legs. (girl, 12 years old)

correlated with the total number of words he or she had used to describe the two animal species $(r=0.763, p<$ 0.001). Similarly, the total sum of words used (plant plus animal descriptions) was positively correlated with the total sum of features and attributes mentioned for the four species $(\mathrm{r}=0.873, \mathrm{p}<0.001)$.

In the linear mixed-models, the number of features and the number of attributes mentioned in the two plant or animal descriptions were not significantly related to children's knowledge of plants or animals, age and sex (plants: all $\mathrm{p}>0.101$; animals: all $\mathrm{p}>0.175$ ).

After data had been aggregated at the level of the class (2-4 children per class), a positive relationship was found between the mean number of animal features or attributes mentioned and the mean number of correctly identified animal taxa (features: $\mathrm{r}=0.70, \mathrm{t}=3.23, \mathrm{p}=$ 0.008; attributes: $\mathrm{r}=0.58, \mathrm{t}=2.33, \mathrm{p}=0.040)$. In case of plants, no such relationship occurred (features: $r=0.04$, $\mathrm{t}=-0.14, \mathrm{p}=0.893$; attributes: $\mathrm{r}=0.03, \mathrm{t}=-0.11, \mathrm{p}=0.918$ ).

At the end of the radio moderations, F. vesca was identified by 12 children as a wild strawberry and by further 32 as a strawberry. In contrast, only one child could identify G. robertianum as a cranesbill. P. pipistrellus was identified by 45 children as a bat and C. coriaceus by 39 children as a beetle.

\section{Importance of Species Knowledge (Research Question 3)}

Overall, $67 \%$ of the children wanted to know the names of plants and animals, $20 \%$ considered it unimportant, and $13 \%$ were undecided. In addition, $41 \%$ of the proponents of species knowledge stated that they only wanted to know the most basic, local or important plants and animals.

Proponents of species knowledge found it personally important and part of their education, and also argued from a utilitarian perspective. Moreover, some saw it as an opportunity to pass on their knowledge to other people, especially to children (Table 6). About $54 \%$ of the children believed that species knowledge is also relevant for society, 39\% found it relevant with limitations and $7 \%$ irrelevant. Most often, it was seen as part of a basic education and important due to utilitarian reasons (see Table 6).

\section{Promoters of Species Knowledge (Research Question 4)}

Family members were clearly the main promoters of species knowledge. However, books were also an information source, while teachers were hardly mentioned (Table 7). Almost a third of the children (17 
Table 6. Personal and societal relevance of species knowledge in view of 46 children. The answers to the open questions were sorted into broad categories

Category (responses) Illustrative examples

Personal Personal importance, basic I am glad I know the names. It is cool. (girl, 11 years old)

relevance education (14) I do not have to know every plant and every beetle by name, but having a basic knowledge of the most relevant species is important to me. (girl, 11 years old)

Utilitarian perspective: It is really good to know the names. Then you know whether you can eat the fruit of a recognition of dangerous or plant. It is important for me to know if they are poisonous. But knowing all the names is edible species, significance not so important. Of course it is good to know them if you are interested, but it is really for future profession (11) not necessary to learn them all by heart. (girl, 10 years old)

Yes, it is very important. If I go to the forest or camping and see a plant or a mushroom, I have to know whether it is poisonous. And names help to know what it is. (boy, 11 years old)

I want to be a carpenter or a farmer and then I must know trees and plants. (boy, 12 years old

Knowledge transfer (6) It is quite practical to see an animal like the deer and know its name. When I go for a walk in the woods and have a small child with me, I can tell what kind of animal it is. (boy, 12 years old)

Nature conservation (2) Of course it is cool if you know a bit about nature: you have to respect it, because you do not know how long it will be around if we continue to do what we do. (girl, 12 years old)

Empathy for species (2) Because I find most plants and animals very beautiful and I think that they are also living beings (girl, 11 years old)

No relevance (9) No. Plants do not interest me and animals are either exciting or boring. (boy, 11 years old)

No explanation given (12)

Societal Basic education (15)

relevance

They must not know all of them, but at least some should be known. It would be a shame not to know them. (boy, 12 years old)

Everyone should be allowed to decide for themselves. If people do not care, they do not have to learn the names. But a little basic knowledge would be great. (girl, 11 years old)

Utilitarian perspective: It is important for our lives. Plants provide us with fruits and animals with meat. (girl, recognition of dangerous or 11 years old)

edible species; significance It is not necessarily important that everyone knows the names. After all, it is their for future profession (14) business. But if you are ever released into the wild, it can be important whether you are looking at a wild strawberry or a nettle. (girl, 12 years old)

Nature conservation (7) They should also know the rare ones so that they are not destroyed. (girl, 12 years old) Animals should be treated as living beings and not as objects and therefore you should know them. We as humans also remember each other's names. (girl, 12 years old)

Knowledge transfer (2) People learn what plants look like and then get to know other plants better. Afterwards they can teach it to others. (boy, 11 years old)

No relevance (3)

No explanation given (14)

persons) emphasized the importance of original encounters with plants and animals in near-natural places: "It helps me when I can see a plant or an animal, touch it and then hear its name. I remember it better than if I only hear a name" (girl, 11 years old). Moreover, eleven children emphasized the importance of frequent repetitions of names (examples in Table 7).

\section{DISCUSSION}

Own (sensual) experiences and observations were frequently reported when children recalled their first encounters with stinging nettles and a diversity of animal species. However, both ways of a first contact with species do not directly lead to their names and to further information about the specimen. Eventually, a person or some other form of help is needed to bring knowledge to the children (Remmele \& Lindemann-
Matthies, 2018). Here, family members, i.e., parents, grandparents and also siblings, were especially named. Similar results were found in pre-school students from Malta (Gatt et al., 2007; Tunnicliffe et al., 2008) and elementary students from Germany (Remmele \& Lindemann-Matthies, 2018; Scherf, 1988). Learning situations, i.e., situations, in which a person had drawn the children's attention to a new plant or animal, were also reported. However, first encounters with animals were much less connected to learning situations than first encounters with plants. One reason could be that children have more emotional attachment to animals than plants (Lindemann-Matthies, 2005) and therefore need less encouragement from other people in getting to know them.

Tunnicliffe and Reiss (2000) established the sequence 'parental home - school - direct observation - media' for the acquisition of plant knowledge. In the present study, 
Table 7. Promoters of species knowledge in view of 46 children. The answers to the open question were sorted into broad categories. Multiple answers were possible. In brackets: number of children who mentioned at least one family member or one media type

\begin{tabular}{|c|c|c|}
\hline Promoter & Responses & Illustrative examples \\
\hline \multicolumn{3}{|l|}{ Family members (42) } \\
\hline Mother & 37 & $\begin{array}{l}\text { My mother always tells me what it is. Half an hour later she asks me what it was and } \\
\text { then I have to repeat it; this way, I can remember the names (boy, } 10 \text { years old). } \\
\text { We go hiking a lot and my mother often asks me what kind of flower it is. Next time, I } \\
\text { know perhaps half of plants, and then I know more and more. (girl, } 12 \text { years old) }\end{array}$ \\
\hline Father & 30 & $\begin{array}{l}\text { My father is a forest worker. When we go for walks, I ask him when I see a tree. He } \\
\text { knows almost every tree by name. (boy, } 12 \text { years old) }\end{array}$ \\
\hline Grandmother & 17 & $\begin{array}{l}\text { My grandmother has a large garden and there she sometimes explains the plants to me. } \\
\text { (girl, } 10 \text { years old) }\end{array}$ \\
\hline Grandfather & 15 & $\begin{array}{l}\text { When I was younger, my grandfather was always with me in the forest looking for } \\
\text { mushrooms and we saw a lot of animals there. (boy, } 10 \text { years old) }\end{array}$ \\
\hline Sibling & 1 & My siblings also tell me names when I ask. (girl, 11 years old) \\
\hline \multicolumn{3}{|l|}{ The media (19) } \\
\hline Books & 17 & $\begin{array}{l}\text { As a little child I wanted to become a researcher. I had lots of nature books and used to } \\
\text { read them every morning and every evening. I wanted to know what plants are like and } \\
\text { what they are called, and from a very young age I tried to remember everything and } \\
\text { now I know it. (boy, } 12 \text { years old) }\end{array}$ \\
\hline Internet & 3 & $\begin{array}{l}\text { There are things that parents sometimes do not know and then the Internet is practical. } \\
\text { (boy, } 11 \text { years old) }\end{array}$ \\
\hline Nature docus & 3 & I have also seen many documentary films (girl, 12 years old) \\
\hline Teachers (6) & & $\begin{array}{l}\text { School helps most of all. At school you look at everything more closely and at home you } \\
\text { just say: this is a dog and this is a lizard. At school you learn the exact names and where } \\
\text { the species live and such stuff. (boy, } 11 \text { years old) }\end{array}$ \\
\hline Nanny or neighbor (5) & & $\begin{array}{l}\text { My childminder always tells me the names of plants and animals and I have to repeat } \\
\text { them. (girl, } 12 \text { years old) }\end{array}$ \\
\hline
\end{tabular}

however, teachers neither played a role in the first encounter with plants or animals nor as a promoter of species knowledge in general (but see Remmele \& Lindemann-Matthies, 2018). It should be noted that first encounters with plants or animals often occurred during early childhood, so that school experiences could not have been named. However, in the last question about the providers of information on plants and animals, teachers were also rather irrelevant. Some children mentioned the media, which was also the case in other countries, where a similar age group had been interviewed (Patrick et al., 2013). However, in the present study, the media most of all meant the use of books about plants and animals, while in other studies the term 'media' was not further specified (Patrick \& Tunnicliffe, 2011) or meant a mixture of television, books, and the internet (Patrick et al., 2013). For children from England, Iceland, and Argentina, the media were also a main 'location' where they got to know animals (Campos et al., 2012; Patrick et al., 2013). This was rather not the case in the present study. The children talked most often about hands-on-experiences with plants and animals, although they were almost all living in rather urban environments.

Hands-on experiences - whether they were positive or negative, initiated or by chance - were most prominent in children's reports about their first encounter with plants and animals. Moreover, several children emphasized the importance of original encounters with organisms in near-natural places when reflecting about the value of species knowledge. These are encouraging results in times when children's experiences of nature are expected to decline (Louv, 2016; Soga \& Gaston, 2016; Soga et al., 2016). However, there are differences between everyday experiences and scientific observations of species, which connect to theory. Only the latter will finally contribute to a deeper understanding of differentiating traits between organisms and to a sound understanding of the diversity of living beings (Eberbach \& Crowley, 2009; Tunnicliffe, 2001). But who will provide the theory? In the present sample from Switzerland, species knowledge was not provided by trained (science) teachers but by parents and grandparents, i.e., depends on their knowledge, their nature orientations and their attitudes towards species (as in Soga et al., 2018). Moreover, in highly industrialized countries such as Switzerland species knowledge is no longer needed to secure people's livelihood (Pilgrim et al., 2008). In consequence, knowledge of plants and animals and their uses, one aspect the participating children were especially interested in, is waning among laypersons - parents and grandparents included - leading to low expectations and perceptions of what might be there (Hooykaas et al., 2019; Leather \& Quicke, 2010; Soga \& Gaston, 2016). In the near future, parents and grandparents might thus no longer function as providers and promoters of species knowledge and nature experiences.

After all, it should be the task of the school, and not the family, to introduce children to the diversity of living 
beings. However, since decades the teaching of taxonomy and systematics at school, once an integral part of biology education (Crisci, 1993) is decreasing in many countries of the world (Barker et al., 2002; Leather \& Quicke, 2009; Pyle 1993), and is only recently brought back in the discussion due to the accelerating loss of biodiversity. 'Species literacy' (Hooykaas et al., 2019) wants to enable humans to distinguish between organisms and thus to understand biological diversity or, in the words of Leather and Quicke (2009, p. 51), to understand that "grass is not 'just grass' but many grasses; that a wasp can be many wasps". In this context it is actually encouraging that most children in the present study considered at least knowledge of typical, local species important and part of a basic education, although their personal motivation to learn about species was not primarily based on ecological considerations, but on personal benefits. Nordic student teachers, on the contrary, expressed most ecological reasons and least utilitarian ones when they were asked about the importance of species knowledge (Palmberg et al., 2018).

In contrast to a German study, where ten-to-elevenyear old students had difficulties characterizing plants at all (Jäkel, 1992), children in the present survey were rather eloquent and used a range of different features and attributes when describing wild strawberry (Fragaria vesca) and herb-Robert (Geranium robertianum). In both plants, children focused first on attributes of the leaves and stems, and only then on those of the flowers. In a recent study with student teachers, flowers and flower color were also of minor interest when identifying plants in nature (Lindemann-Matthies et al., 2017). This is remarkable as most determination books for laypersons are sorted by flower color (e.g., Schauer \& Caspari, 2010; Spohn et al., 2015). Color, however, was important when children described the various plant organs in detail, but it was not solely reserved for the flower descriptions. In case of animals, color was also a frequently mentioned attribute (as in Jäkel, 1992). When describing animals, children focused primarily on the body of an organism and then on a range of other species-specific features. Primary student teachers in Nordic-Baltic countries and Germany also focused first on the body, i.e., its size, shape and color, when identifying animals in nature (Lindemann-Matthies et al., 2017; Palmberg et al., 2015). In case of the leather beetle (Carabus coriaceus), many children referred to its legs and antennae in addition to the body, which was also done by children of similar ages from the United States when describing insects (Shepardson, 2002).

The mean number of characteristic animals traits mentioned increased with the mean knowledge of animal species of a class - or vice-versa. One explanation could be that a trained eye detects certain traits in organisms and, even without knowing names in the first place, might start to differentiate species accordingly.
Once the names are provided, they might stay in memory. Another explanation could be that species knowledge, howsoever acquired, leads to a comparison of organisms and thus to the perception of characteristic traits. As it might be, close observations of organisms and a training of characteristic traits are inevitable when species knowledge is taught (Eberbach \& Crowley, 2009). Nowadays, species identification can be done in many ways, e.g., with videos and apps for mobile devices (e.g., Kumar et al., 2012; Pfeiffer et al., 2011). However, dichotomous or other identification keys have a great advantage over app-based tools or mere picture books as they ask detailed questions about characteristic plant or animal traits, which, in time, might be remembered and used to distinguish between species.

The assumption that taxonomy is perceived as something boring (Leather \& Quicke, 2009) could not be supported by the present data. The children had little problems in communicating enthusiastically and, in terms of their own perception, knowledgably about the different features and their appearances (as in Braund, 1998; Condon, 1995), and enjoyed the simulated radio moderation. The children not only enjoyed the identification task, but had in general a rather positive attitude towards the species presented. With the exception of stinging nettles, more positive than negative memories were recalled. Similar results were found in a previous study from Switzerland, where nineto-thirteen-year-old children were asked to comment on 18 invertebrate species which were shown to them as pictures (Breuer et al., 2015). This indicates that plants and invertebrates are probably better than their reputation.

Finally, we have to acknowledge that our sample of 46 children was rather small and only from one area of Switzerland. A critical aspect was also the question of the first encounter with species. It can be assumed that some children could not recall their very first encounter. Nevertheless, we consider the results to be valuable, as they provide information about events and persons that are important for children when encountering species, and about emotions associated with certain organisms. In the simulated radio moderation, children wanted to show off their knowledge if they were already familiar with the organisms they had to describe. This could be seen in case of Fragaria vesca and Pipistrellus pipistrellus, two well-known species by children in Switzerland. Here, some children focused more on the usefulness of the strawberry or the ecology of the bat rather than on their important body parts. This could be avoided if the radio moderation technique is only used when organisms are not yet known to children. We must also acknowledge that a mere counting of words in children's reports does not necessarily say something about the quality of a description. However, the strong correlation between the number of words used and the number of characteristic traits mentioned demonstrates that the 
children were rather specific when describing the plants and animals presented. Another limitation was the small number of species that had to be described. In order to be able to draw more substantiated conclusions, more species from more taxonomic groups have to be included. In addition, it would be advisable to use eye trackers to investigate which features are being looked at and in what order.

\section{CONCLUSIONS}

The storytelling approach helped children to recall well their first encounter with plants and animals. Moreover, the simulated radio moderation was enjoyable and motivating to detect characteristic traits of organisms. Both methods can therefore be recommended for classroom education when dealing with species and species traits. Children's experiences and emotions during their first encounter with species were rather positive, even in case of insects, and were often due to direct observations in nearby natural places. However, if first encounters with organisms and species knowledge in general almost solely depend on (untrained) family members, as in the present study, children might be deprived of hands-on investigations of plants and animals, depending on their family's nature orientation and attitudes towards organisms. In times of low biodiversity perception among laypersons but increasing biodiversity loss, it has to be the task of the school to foster species literacy, and the task of universities to train student teachers accordingly. It is thus highly recommended to promote scientific competencies in the classroom such as observation and classification, and to emphasize outdoor experiences. Outdoor experiences can significantly relieve "plant blindness" (Fančovičová \& Prokop, 2011) and foster positive attitudes towards species other than "loveable mammals" (Lindemann-Matthies, 2005). One of the easiest available outdoor environments is the school ground, which could be transformed into an outside classroom by introducing a variety of wild flowers and trees, creating small garden areas for crops, or shaping a pond. Naturalized school grounds or school gardens can offer students multiple opportunities to get familiar with the diversity of local plants and animals (LindemannMatthies \& Köhler, 2019).

In case of animals, species knowledge and the number of traits children could apply during the determination process were positively related. However, further studies are needed to investigate whether their actually is a link between the knowledge of traits and species knowledge. To build on the ideas of children, it could be meaningful to develop plant identification tools that primarily focus on leaves or other traits instead of flower color. Children considered species knowledge important and should not be deprived of it. When introducing plants or animals, their uses could be especially emphasized to meet children's prior interests. Going beyond the present results, we finally hope that children will be given multiple opportunities for nature experiences not only at home but also in school to keep them healthy and happy as well.

Author contributions: All authors have sufficiently contributed to the study, and agreed with the results and conclusions.

Funding: No funding source is reported for this study.

Declaration of interest: No conflict of interest is declared by authors.

\section{REFERENCES}

Albert, C., Luque, G. M., \& Courchamp, F. (2018). The twenty most charismatic species. PLOS One, 13(7), e0199149.

https:/ / doi.org/10.1371/journal.pone.0199149

Balas, B., \& Momsen, J. L. (2014). Attention "blinks" differently for plants and animals. CBE Life Sciences Education, 13, 437-443. https://doi.org/10.1187/ cbe.1405-0080

Barker, S., Slingsby, D., \& Tilling, S. (2002). Teaching biology outside the classroom. Is it heading for extinction? Field Studies Council Occasional Publication 72. Field Studies Council.

Barrett, H. C., \& Broesch, J. (2012). Prepared social learning about dangerous animals in children. Evolution and Human Behavior, 33, 499-508. https://doi.org/10.1016/j.evolhumbehav.2012.01. 003

Batt, S. (2009). Human attitudes towards animals in relation to species similarity to humans: a multivariate approach. Bioscience Horizons, 2, 180190. https:/ / doi.org/10.1093/biohorizons/hzp021

Bermudez, G. M., Battistón, L. V., Capocasa, M. C. G., \& De Longhi, A. L. (2017). Sociocultural variables that impact high school students' perceptions of native fauna: a study on the species component of the biodiversity concept. Research in Science Education, 47, 203-235. https://doi.org/10.1007/s11165-0159496-4

Bermudez, G. M., \& Lindemann-Matthies, P. (2020). "What matters is species richness" - high school students' understanding of the components of biodiversity. Research in Science Education, 50, 21592187. https:/ / doi.org/10.1007/s11165-018-9767-y

Bögeholz, S. (2006). Nature experience and its importance for environmental knowledge, values and action: recent German empirical contributions. Environmental Education Research, 12, 65-84. https:/ / doi.org/10.1080/13504620500526529

Bollnow, O. F. (1966). Sprache und Erziehung [Language and education] (3rd ed.). Kohlhammer.

Borgi, M., \& Cirulli, F. (2015). Attitudes toward animals among kindergarten children: Species preferences. 
Anthrozoös, 28, 45-59. https://doi.org/10.2752/ 089279315X14129350721939

Braund, M. (1998). Trends in children's concepts of vertebrate and invertebrate. Journal of Biological Education, 32, 112-118. https://doi.org/10.1080/ 00219266.1998.9655606

Breuer, G. B., Schlegel, J., Kauf, P., \& Rupf, R. (2015). The Importance of Being Colorful and Able to Fly: interpretation and implications of children's statements on selected insects and other invertebrates. International Journal of Science Education, 37, 2664-2687. https:/ / doi.org/10.1080/ 09500693.2015.1099171

Bringolf-Isler, B., Grize, L., Ruch, N., Sennhauser, F. H., \& Braun-Fahrländer, C. (2010). Built environment, parents' perception, and children's vigorous outdoor play. Preventive Medicine, 50, 251-256. https:/ / doi.org/10.1016/j.ypmed.2010.03.008

Campos, C. M., Greco, S., Ciarlante, J. J., Balangione, M., Bender, J. B., Nates, J., \& Lindemann-Matthies, P. (2012). Students' familiarity and initial contact with species in the Monte desert (Mendoza, Argentina). Journal of Arid Environments, 82, 98-105. https:/ / doi.org/10.1016/j.jaridenv.2012.02.013

Carmi, N., Arnon, S., \& Orion, N. (2015). Transforming environmental knowledge into behavior: the mediating role of environmental emotions. The Journal of Environmental Education, 46, 183-201. https:/ / doi.org/10.1080/00958964.2015.1028517

Chawla, L. (2015). Benefits of nature contact for children. Journal of Planning Literature, 30, 433-452. https:// doi.org/10.1177/0885412215595441

Clements, R. (2004). An investigation of the status of outdoor play. Contemporary Issues in Early Childhood, 5, 68-80. https://doi.org/10.2304/ ciec.2004.5.1.10

Condon, M. (1995). Biodiversity, systematics, and Tom Sawyer science. Conservation Biology, 9(4), 711-714. https://doi.org/10.1046/j.1523-1739.1995.0904071 1.x

Crisci, J. V. (1993). Order $\mathcal{E}$ diversity in the living world: Teaching taxonomy \& systematics in schools. National Association of Biology Teachers (NABT), 11250 Roger Bacon Drive, \# 19, Reston, VA 22090.

Eberbach, C., \& Crowley, K. (2009). From everyday to scientific observation: how children learn to observe the biologist's world. Review of Educational Research, 79, 39-68. https://doi.org/10.3102/ 0034654308325899

Fančovičová, J., \& Prokop, P. (2011). Plants have a chance: outdoor educational programmes alter student's knowledge and attitudes towards plants. Environmental Education Research, 17, 537-551. https:// doi.org/10.1080/13504622.2010.545874
Galli, L. G., \& Meinardi, E. (2015). Obstáculos para el aprendizaje del modelo de evolución por selección natural, en estudiantes de escuela secundaria de Argentina [Obstacles to learning the evolution by natural selection model in high school students from Argentina]. Ciência \& Educação (Bauru), 21, 101-122.

https:/ / doi.org/10.1590/1516731320150010007

Gatt, S., Tunnicliffe, S. D., Borg, K., \& Lautier, K. (2007). Young Maltese children's ideas about plants. Journal of Biological Education, 41, 117-122. https:// doi.org/10.1080/00219266.2007.9656080

Gill, T. (2014). The benefits of children's engagement with nature: A systematic literature review. Children Youth and Environments, 24, 10-34. https:// doi.org/10.7721/chilyoutenvi.24.2.0010

Hooykaas, M. J., Schilthuizen, M., Aten, C., Hemelaar, E. M., Albers, C. J., \& Smeets, I. (2019). Identification skills in biodiversity professionals and laypeople: A gap in species literacy. Biological Conservation, 238, e108202. https:/ / doi.org/10.1016/j.biocon.2019.108202

Huxham, M., Welsh, A., Berry, A., \& Templeton, S. (2006). Factors influencing primary school children's knowledge of wildlife. Journal of Biological Education, 41, 9-12. https://doi.org/ 10.1080/00219266.2006.9656050

Jäkel, L. (1992). Lernvoraussetzungen von Schülern in bezug auf Sippenkenntnis [Learning requirements of pupils with regard to taxonomic knowledge]. Unterricht Biologie, 16(172), 40-41.

Kellert, S. R., \& Westervelt, M. O. (1983). Historical trends in American animal use and perception. International Journal for the Study of Animal Problems, 4(2), 133-146.

Kellert, S. R. (1993). The biological basis for human values of nature. In S. R. Kellert, \& E. O. Wilson (Eds.), The biophilia hypothesis (pp. 43-69). Island Press.

Kensinger, E. A., \& Schacter, D. L. (2016). Memory and emotion. In L. Feldman Barrett, M. Lewis, \& J. M. Haviland (Eds.), Handbook of emotions (pp. 564-578). Guilford Press.

Kumar, N., Belhumeur, P. N., Biswas, A., Jacobs, D. W., Kress, W. J., Lopez, I. C., \& Soares, J. V. B. (2012). Leafsnap: A computer vision system for automatic plant species identification. In A. Fitzgibbon, S. Lazebnik, P. Perona, Y. Sato, \& C. Schmid (Eds.), Computer vision -ECCV 2012 (pp. 502-516). Springer. https://doi.org/10.1007/978-3-64233709-3_36

Leather, S. R., \& Quicke, D. J. L. (2009). Where would Darwin have been without taxonomy? Journal of Biological Education, 43, 51-52. https:// doi.org/10.1080/00219266.2009.9656151 
Leather, S. R., \& Quicke, D. J. L. (2010). Do shifting baselines in natural history knowledge threaten the environment? The Environmentalist, 30, 1-2. https:/ / doi.org/10.1007/s10669-009-9246-0

Lindemann-Matthies, P. (2005). "Loveable" mammals and "lifeless" plants: How children's interest in common local organisms can be enhanced through observation of nature. International Journal of Science Education, 27, 635-677. https://doi.org/10.1080/ 09500690500038116

Lindemann-Matthies, P., Remmele, M., \& Yli-Panula, E. (2017). Professional competence of student teachers to implement species identification in schools - a case study from Germany. CEPS Journal, 7(1), 29-47. https:/ / doi.org/10.26529/cepsj.12

Lindemann-Matthies, P., \& Köhler, K. (2019). Naturalized versus traditional school grounds: Which elements do students prefer and why? Urban Forestry \& Urban Greening, 46, 126475. https://doi.org/10.1016/j.ufug.2019.126475

Louv, R. (2006). Last child in the woods. Saving our children from nature-deficit disorder. Algonquin books of Chapel Hill.

Mullan, K. (2019). A child's day: Trends in time use in the UK from 1975 to 2015. The British Journal of Sociology, 70, 997-1024. https://doi.org/10.1111/ 1468-4446.12369

New, J., Cosmides, L., \& Tooby, J. (2007). Categoryspecific attention for animals reflects ancestral priorities, not expertise. Proceedings of the National Academy of Sciences, 104, 16598-16603. https:/ / doi.org/10.1073/pnas.0703913104

Palmberg, I., Berg, I., Jeronen, E., Kärkkäinen, S., Norrgård-Sillanpää, P., Persson, C., Vilkonis, R., \& Yli-Panula, E. (2015). Nordic-Baltic student teachers' identification of and interest in plant and animal species: The importance of species identification and biodiversity for sustainable development. Journal of Science Teacher Education, 26, 549-571. https://doi.org/10.1007/s10972-0159438-z

Palmberg, I., Hermans, M., Jeronen, E., Kärkkäinen, S., Persson, C., \& Yli-Panula, E. (2018). Nordic student teachers' views on the importance of species and species identification. Journal of Science Teacher Education, 29, 397-419. https://doi.org/10.1080/ 1046560X.2018.1468167

Papworth, S. K., Rist, J., Coad, L., \& Milner-Gulland, E. J. (2009). Evidence for shifting baseline syndrome in conservation. Conservation Letters, 2, 93-100. https://doi.org/10.1111/j.1755-263X.2009.00049.x

Patrick, P., \& Tunnicliffe, S. D. (2011). What plants and animals do early childhood and primary students' name? Where do they see them? Journal of Science
Education and Technology, 20, 630-642. https:/ / doi.org/10.1007/s10956-011-9290-7

Patrick, P., Byrne, J., Tunnicliffe, S. D., Asunta, T., Carvalho, G., Havu-Nuutinen, S., ..., \& Tracana, R. B. (2013). Students (ages 6, 10, 15 years) in six countries knowledge of animals. Nordic Studies in Science Education, 9, 18-32. https://doi.org/ $10.5617 /$ nordina. 624

Pfeiffer, V. D., Scheiter, K., Kühl, T., \& Gemballa, S. (2011). Learning how to identify species in a situated learning scenario: using dynamic-static visualizations to prepare students for their visit to the aquarium. Eurasia Journal of Mathematics, Science $\mathcal{E}$ Technology Education, 7, 135-147. https:// doi.org/10.23668/psycharchives.724

Pilgrim, S. E., Cullen, L. C., Smith, D. J., \& Pretty, J. (2008). Ecological knowledge is lost in wealthier communities and countries. Environmental Science $\mathcal{E}$ Technology, 42, 1004-1009. https://doi.org/ $10.1021 /$ es070837v

Prezza, M., Alparone, F., Cristallo, C. \& Secchiano, L. (2005). Parental perception of social risk and of positive potentiality of outdoor autonomy for children: The development of two instruments. Journal of Environmental Psychology, 25, 437-453. https:/ / doi.org/10.1016/j.jenvp.2005.12.002

Prokop, P., \& Randler, C. (2018). Biological predispositions and individual differences in human attitudes toward animals. In R. R. N. Alves, \& U. P. de Albuquerque (Eds.), Ethnozoology: animals in our lives (pp. 447-466). Academic Press.

Pyle, R. M. (1993). The thunder tree: Lessons from an urban wildland. Houghton Mifflin.

Pyle, R. M. (2002). Eden in a vacant lot: Special places, species, and kids in the neighborhood of life. In P. H. Kahn, Jr., \& S. R. Kellert (Eds.), Children and nature: Psychological, sociocultural, and evolutionary investigations (pp. 305-327). MIT Press.

Randler, C., \& Bogner, F. (2002). Comparing methods of instruction using bird species identification skills as indicators. Journal of Biological Education, 36, 181188.

https:/ / doi.org/10.1080/00219266.2002.9655830

Randler, C. (2008). Teaching species identification - a prerequisite for learning biodiversity and understanding ecology. Eurasia Journal of Mathematics, Science E Technology Education, 4(3), 223-231. https:/ / doi.org/10.12973/ejmste/75344

Remmele, M., \& Lindemann-Matthies, P. (2018). Like father, like son? On the relationship between parents' and children's familiarity with species and sources of knowledge about plants and animals. Eurasia Journal of Mathematics, Science \& Technology Education, 14(10), em1581. https://doi.org/ 10.29333 / ejmste/ 92287 
Rideout, V. J., Foehr, U. G., \& Roberts, D. F. (2010). Generation $\mathrm{M}^{2}$ : media in the lives of 8-to 18-year-olds. Henry J. Kaiser Family Foundation.

Schauer, T., \& Caspari, C. (2010). Der BLV Pflanzenführer für unterwegs [The BLV plant guide on the road] (4th ed.). BLV.

Scherf, G. (1988). Kenntnis häufiger Pflanzen des Straßenrandes und Vorstellungen über Pflanzen bei 9-12jährigen Schülern und bei jungen Erwachsenen (Lehramtstudenten und Schülern einer Fachakademie für Sozialpädagogik) [Knowledge of common roadside plants and ideas about plants of 9-12 year old students and young adults (students of a teachers' training college and students of an academy of social work)]. Sachunterricht und Mathematik in der Primarstufe, 16(9), 196-204.

Schussler, E. E., \& Olzak, L. A. (2008). It's not easy being green: Student recall of plant and animal images. Journal of Biological Education, 42, 112-119. https:/ / doi.org/10.1080/00219266.2008.9656123

Shepardson, D. P. (2002). Bugs, butterflies, and spiders: children's understandings about insects. International Journal of Science Education, 24, 627-643. https://doi.org/10.1080/09500690110074765

Slingsby, D. (2009). Charles Darwin, biological education and diversity: past present and future. Journal of Biological Education, 43, 99-100.

Soga, M., \& Gaston, K. J. (2016). Extinction of experience: The loss of human-nature interactions. Frontiers in Ecology and the Environment, 14, 94-101. https://doi.org/10.1002/fee.1225

Soga, M., Gaston, K. J., Koyanagi, T. F., Kurisu, K., \& Hanaki, K. (2016). Urban residents' perceptions of neighbourhood nature: Does the extinction of experience matter? Biological Conservation, 203, 143150. https:/ / doi.org/10.1016/j.biocon.2016.09.020

Soga, M., Yamanoi, T., Tsuchiya, K., Koyanagi, T. F., \& Kanai, T. (2018). What are the drivers of and barriers to children's direct experiences of nature? Landscape and Urban Planning, 180, 114-120. https:/ / doi.org/10.1016/j.landurbplan.2018.08.015

Spohn, M., Golte-Bechtle, M., \& Spohn, R. (2015). Was blüht denn da? [What is flowering?]. Kosmos.

Tandon, P. S., Zhou, C., \& Christakis, D. A. (2012). Frequency of parent-supervised outdoor play of US preschool-aged children. Archives of Pediatrics $\mathcal{E}$ Adolescent Medicine, 166, 707-712. https:/ / doi.org/10.1001/archpediatrics.2011.1835

Tomkins, S. P., \& Tunnicliffe, S. D. (2015). Naming the living world: From the infant's perception of animacy to a child's species concept. In C. J. Boulter, \& D. Sanders (Eds.), New directions in mathematics and science education. Darwin-inspired learning (pp. 147-163). Sense Publishers. https:/ / doi.org/10.1007/978-94-6209-833-6_12

Tunnicliffe, S. D., \& Reiss, M. J. (1999). Building a model of the environment: How do children see animals? Journal of Biological Education, 33, 142-148. https:/ / doi.org/10.1080/00219266.1999.9655654

Tunnicliffe, S. D., \& Reiss, M. J. (2000). Building a model of the environment: how do children see plants? Journal of Biological Education, 34, 172-177. https:/ / doi.org/10.1080/00219266.2000.9655714

Tunnicliffe, S. D. (2001). Talking about plants comments of primary school groups looking at plant exhibits in a botanical garden. Journal of Biological Education, 36, 27-34. https:/ / doi.org/10.1080/00219266.2001.9655792

Tunnicliffe, S. D., Gatt, S., Agius, C., \& Pizzuto, S. A. (2008). Animals in the lives of young Maltese Children. Eurasia Journal of Mathematics, Science $\mathcal{E}$ Technology Education, 4(3), 215-221. https://doi.org/10.12973/ ejmste/75343

Wandersee, J. H., \& Schussler, E. E. (1999). Preventing plant blindness. The American Biology Teacher, 61, 82-86. https://www.jstor.org/stable/4450624

Wandersee, J. H., \& Schussler, E. E. (2001). Toward a theory of plant blindness. Plant Science Bulletin, 47, 2-12.

Yorek, N., Şahin, M., \& Aydın, H. (2009). Are animals 'more alive' than plants? Animisticanthropocentric construction of life concept. Eurasia Journal of Mathematics, Science and Technology Education, 5, 369-378. https:/ / doi.org/10.12973/ ejmste/75287

Zucchi, H. (2007). Zur Bedeutung und zum Erwerb von Artenkenntnissen [On the importance and acquisition of species knowledge]. Unterricht Biologie, 324, 44-45. 


\section{APPENDIX 1}

\section{Species Presented in the First Part of the Interview}

Each child $(n=47)$ received one plant and one animal from the list. No: number of children to whom the species were shown

\begin{tabular}{|c|c|c|c|}
\hline Plants & No & Animals & No \\
\hline Bellis perennis & 5 & Anguis fragilis & 3 \\
\hline Betula pendula & 4 & Bufo bufo & 3 \\
\hline Fagus sylvatica & 4 & Salmo trutta fario & 2 \\
\hline Sorbus aucuparia & 4 & Ichthyosaura alpestris & 2 \\
\hline Hedera helix & 3 & Muscardinus avellanarius & 2 \\
\hline Trifolium pratense & 3 & Passer domesticus & 2 \\
\hline Quercus robur & 3 & Erinaceus europaeus & 2 \\
\hline Rubus idaeus & 3 & Arvicola terrestris & 2 \\
\hline Ranunculus acris & 3 & Crocidura russula & 2 \\
\hline Acer pseudoplatanus & 2 & Martes foina & 2 \\
\hline Abies alba & 2 & Lacerta agilis & 1 \\
\hline Rubus fruticosus & 2 & Aphis sambuci & 1 \\
\hline Leucanthemum vulgare & 2 & Fringilla coelebs & 1 \\
\hline Phragmites australis & 1 & Perca fluviatilis & 1 \\
\hline Sambucus nigra & 1 & Sciurus europaeus & 1 \\
\hline Vaccinium myrtillus & 1 & Pica pica & 1 \\
\hline Corylus avellana & 1 & Gryllus campestris & 1 \\
\hline Prunus avium & 1 & Lepus europaeus & 1 \\
\hline Papaver rhoeas & 1 & Salamandra salamandra & 1 \\
\hline \multirow[t]{16}{*}{ Aesculus hippocastaneum } & 1 & Pyrrhocoris apterus & 1 \\
\hline & & Vulpes vulpes & 1 \\
\hline & & Araneus diadematus & 1 \\
\hline & & Rana temporaria & 1 \\
\hline & & Phoenicurus ochrurus & 1 \\
\hline & & Esox lucius & 1 \\
\hline & & Parus major & 1 \\
\hline & & Apus apus & 1 \\
\hline & & Talpa europaeus & 1 \\
\hline & & Forficula auricula & 1 \\
\hline & & Capreolus capreolus & 1 \\
\hline & & Episyrphus balteatus & 1 \\
\hline & & Anas platyrhynchos & 1 \\
\hline & & Opiliones sp. & 1 \\
\hline & & Sus scrofa & 1 \\
\hline & & Ixodes ricinus & 1 \\
\hline
\end{tabular}




\section{APPENDIX 2}

\section{Typical Characteristics of Species Used in the Simulated Radio Moderation}

Wild strawberry (Fragaria vesca)

5-20 cm high, with long above-ground runners; basal leaves long stalked, 3-lobed, partial leaves $2-5 \mathrm{~cm}$ long, inverted ovate, wedge-shaped at base, toothed, terminal dentition not smaller than adjacent teeth; flowers white, 1-1.5 cm in diameter, in a sparsely flowered, umbellate inflorescence; hairs of flower stems erect or attached; fruit a red, fleshy false berry; calyx protruding from ripe fruit and not tearing off (composed from Lauber et al., 2018).

Herb-Robert (Geranium robertianum)

10-50 cm tall, ascending or upright, stems often reddish; the leaves also turn red at the end of the flowering season; leaves are deeply dissected, ternate to palmate; sepals and petals 5 each, 10 orange stamens, petals bright pink, with long nail, sepals garnet; fruit long beaked, parts of beak curved outwards after opening, $1.5-2.5 \mathrm{~cm}$ long; calyx and pedicels with glandless or glandular hairs up to $3 \mathrm{~mm}$ long (composed from Lauber et al., 2018).

Common pipistrelle (Pipistrellus pipistrellus)

Small to very small eyes, head-torso length 33-52 mm; short, broad ears, short, blunt and curved tragus; dorsal fur chestnut-brown to blackish-brown, ventral fur tawny, ears, membranous facial area, flight skins and feet blackbrown to black; basic characteristics: four limbs; forelimbs adapted as wings, arms and fingers with very thin bones, flying with very long spread-out digits covered with a thin membrane (patagium); small, pointed teeth; claws on toes (compiled from Hausser, 1995).

Leather beetle (Carabus coriaceus)

30-40 mm long, black; long legs; long slender antennae; strong mandibles; wings; neck shield with fine wrinkled surface; well visible eyes; basic characteristics: three body parts (head, thorax, abdomen); hard outer skeleton; wing covers covering the abdomen; articulated legs and antennae, legs with well-developed claws; mouth parts with four feelers (compiled from Willner, 2013).

\section{http://www.ejmste.com}

